\title{
Perilaku store switching dalam berbelanja online
}

\author{
Dita Amanah ${ }^{1}$, Ratih Hurriyati ${ }^{2}$, Vanessa Gaffar ${ }^{3}$, Lili Adi Wibowo ${ }^{4}$, Dedy Ansari Harahap ${ }^{5}$ \\ Universitas Pendidikan Indonesia ${ }^{1,2,3,4,5}$ \\ Universitas Negeri Medan ${ }^{1}$ \\ Universitas Islam Sumatera Utara ${ }^{5}$
}

\begin{abstract}
ABSTRAK
Artikel ini memaparkan pengaruh ketidakpuasan konsumen dan kebutuhan mencari variasi terhadap perilaku perpindahan toko online dari Tokopedia ke Lazada. Sampel berjumlah 95 responden yang merupakan mahasiswa Fakultas Ekonomi Universitas Negeri Medan dengan sampel bertujuan sebagai teknik pengambilan sampel. Kuesioner digunakan sebagai alat pengumpulan data dan kemudian dianalisis dengan metode regresi linear berganda. Hasil persamaan yang diperoleh adalah $\mathrm{Y}=0,723+0,371 \mathrm{X}_{1}+0,435 \mathrm{X}_{2}+\varepsilon$. Hasil uji $\mathrm{F}(43,413)$ menunjukkan bahwa ketidakpuasan konsumen dan kebutuhan mencari variasi secara simultan berpengaruh positif dan signifikan terhadap perilaku perpindahan konsumen dari toko online Tokopedia ke Lazada. Secara parsial, ketidakpuasan konsumen $(3,368)$ dan kebutuhan mencari variasi $(4,638)$ berpengaruh positif dan signifikan terhadap perilaku perpindahan konsumen dari Tokopedia ke Lazada. Nilai koefisien determinasi $\left(\mathrm{R}^{2}\right)$ adalah 0,486 yang berarti bahwa 48,6\% ketidakpuasan konsumen dan kebutuhan mencari variasi mampu menjelaskan perilaku perpindahan konsumen. Selebihnya $51,4 \%$ dijelaskan oleh variabel lain di luar penelitian. Pemasar online sebaiknya memperhatikan kedua variabel ini dalam mengembangkan strategi bisnisnya sehingga dapat mempertahankan pelanggan untuk tidak berpindah ke toko online pesaing.
\end{abstract}

Kata Kunci : Ketidakpuasan, Kebutuhan mencari variasi, Perilaku perpindahan, Toko Online

\section{ABSTRACT}

This article describes the effect of consumer dissatisfaction and the need to find variations on the behavior of online store switching from Tokopedia to Lazada. Samples were 95 respondents who are students of Faculty of Economics, Universitas Negeri Medan with purposive sampling as a sampling technique. The questionnaire was employed as a data collection tool and then analyzed by multiple linear regression method. The result of the regression is $Y=0.723+$ $0.371 X 1+0.435 X 2+\varepsilon$. The result of $F$ test (43.413) shows that consumer dissatisfaction and the need to find variation simultaneously have a positive and significant effect on the behavior of consumer switch from Tokopedia to Lazada. Partially, consumer dissatisfaction (3.368) and the need for variation (4.638) have a positive and significant effect on consumer switching behavior from Tokopedia to Lazada. The determination coefficient (R2) is 0.486 which means that $48.6 \%$ consumer dissatisfaction and the need to find variation can explain the behavior of consumer switching. The remaining 51.4\% explained by other variables outside the study. Online marketers should pay attention to these two variables in developing their business strategies to keep customers moving from an online store to another.

Keywords : Dissatisfaction, Variation seeking, Switching behavior, Online store

\section{Pendahuluan}

Beberapa tahun belakangan, Indonesia kebanjiran pelaku e-Commerce. Mereka berlomba-lomba memikat pengguna internet tanah air yang memang belakangan mulai tumbuh. Para pelaku e-Commerce itu datang dari beragam latar belakang baik dari dalam dan luar negeri dengan sokongan dana yang tak sedikit pula. Seiring waktu, e-commerce yang menjamur mulai mengerucut menciptakan daftar papan atas layanan tersebut. Seperti data yang dikumpulkan oleh iPrice, situs aggregator online shoping, memperlihatkan bahwa Lazada dan Tokopedia terlibat persaingan sengit. Persaingan yang dimaksud dilihat dari jumlah pengunjung dan popularitas di media social. Lazada menduduki peringkat pertama dengan 49 juta pengunjung diikuti Tokopedia dengan angka 39,7 juta (Prihadi, 2017).

Semakin banyaknya kompetitor di bisnis online, tentu akan meningkatkan persaingan untuk merebut hati konsumen. Pertumbuhan toko online baru yang kian hari kian menjamur bisa saja mengancam perkembangan toko online tertentu. Persaingan yang ketat akan membuat penjualan suatu toko online menjadi lesu jika tidak mampu memenangkannya. 
Persaingan di dunia online menjadi suatu kewajaran karena bisnis ini menawarkan keuntungan yang sangat besar. Oleh karena itu, masing-masing pemasar online harus melakukan sesuatu untuk bisa bertahan dan berkembang menghadapi persaingan. Persaingan toko online untuk menggaet pelanggan yang demikian ketat biasanya sedikit banyak akan memunculkan kompetisi yang kurang sehat dalam berbisnis. Segala cara akan dilakukan demi untuk mendapatkan pelanggan (Admin, 2017b). Berbagai strategi dan ide yang matang harus dimiliki pemasar online. Misalnya menawarkan produk yang unggul, layanan yang maksimal, mengadakan promosi, bermain harga dan sebagainya (Admin, 2017a).

Berbelanja online merupakan fenomena yang tidak bisa dipungkiri lagi. Country General Manager Shopback Indonesia, Indra Yonathan mengatakan penjualan melalui ecommerce terus mengalami peningkatan. Pernyataan ini berdasar hasil survei yang dilakukan pihaknya pada 2.400 responden di tujuh kota. Dari survei terlihat 92,3\% responden makin sering berbelanja online dibanding tahun lalu. Bahkan mereka kini mengaku makin jarang berbelanja offline lantaran makin banyaknya e-commerce di Tanah Air. Dengan makin banyaknya ecommerce memicu adanya shifting dari offline ke online. Dalam sebulan, mayoritas responden mengaku berbelanja online sampai 3-5 kali. Alasannya, berbelanja online dirasa lebih lebih nyaman, barang lebih lengkap, dan harganya pun kerap lebih murah ketimbang offline. Tidak perlu macet dan parkir, jadi konsumen lebih pilih belanja online. Sejumlah promosi pun makin menggiatkan responden untuk berbelanja online. Apalagi bila promosi tersebut dalam bentuk diskon dan bebas ongkos kirim (Rahman, 2017).

Berdasarkan survei yang dilakukan oleh platform yang mewadahi toko dan transportasi online, Shopback menghasilkan tiga toko yang paling disukai oleh konsumen. Yang berada di peringkat pertama adalah e-commerce Tokopedia kemudian diikuti Shopee dan Lazada (Handayani \& Maharani, 2017).
Masing-masing mengembangkan strategi untuk menarik konsumen berbelanja di toko online mereka. Hasilnya, sebanyak 92,3 persen konsumen mengatakan aktivitas belanja online mereka di tahun ini meningkat jika dibandingkan dengan aktivitas di tahun sebelumnya. Terdapat 83 persen konsumen bahkan mengaku telah mengurangi aktivitas berbelanja offline. Meskipun demikian, tidak dapat dihindari kemungkinan terjadinya pelanggan yang berhenti menjadi pelanggan yang kemudian pindah membeli di toko online lain. Hal ini mengindikasikan adanya perilaku perpindahan merek (Ishadi, 2012). Brand switching adalah perpindahan merek yang dilakukan oleh pelanggan untuk setiap waktu penggunaan (Handayai, 2016). Peralihan merek (brand switching) ditandai dengan keterlibatan yang rendah (low involvement). Peralihan merek adalah saat dimana seorang pelanggan atau sekelompok pelanggan berpindah kesetiaan dari satu merek sebuah produk tertentu ke merek produk lainnya (Spacey, 2017).

Ketidakpuasan konsumen merupakan salah satu faktor penyebab terjadinya perpindahan merek karena pelanggan yang tidak puas akan mencari informasi pilihan produk lain, dan mungkin akan berhenti membeli produk atau mempengaruhi orang lain untuk tidak membeli (Kotler \& Keller, 2012). Konsumen yang tidak puas mungkin akan berusaha mengurangi ketidakpuasan tersebut dengan membuangnya atau mengurangi ketidakpuasan dengan mencari informasi yang bisa memperkuat nilai produk tersebut. Sesuai dengan penelitian yang pernah dilakukan oleh (Arianto, 2013), yang menyatakan bahwa ketidakpuasan konsumen berpengaruh positif terhadap perilaku perpindahan merek.

Kebutuhan mencari variasi (variety seeking), juga telah diidentifikasi sebagai faktor yang mempengaruhi keputusan perpindahan merek (Trijp, Hoyer, \& Inman, 1996). Kebutuhan mencari variasi adalah sebuah komitmen kognitif untuk membeli merek yang berbeda karena berbagai alasan yang berbeda, keinginan baru atau timbulnya 
rasa bosan pada sesuatu yang telah lama dikonsumsi (Peter, Olson, \& Grunert, 1999). Karena konsumen dihadapkan dengan berbagai macam variasi produk dengan berbagai jenis merek, keadaan ini dapat mempengaruhi konsumen untuk mencobacoba berbagai macam produk dan merek sehingga konsumen tidak akan sepenuhnya setia akan suatu produk. Berdasarkan uraian di atas, maka peneliti tertarik untuk memahami pengaruh ketidakpuasan konsumen dan kebutuhan mencari variasi terhadap perilaku perpindahan toko dari Tokopedia ke Lazada oleh konsumen.

\section{Tinjauan Pustaka}

\subsection{Perpindahan Merek (Brand Switching)}

\subsubsection{Pengertian Perpindahan Merek}

Perpindahan merek (brand switching) adalah pola pembelian yang dikarakteristikkan dengan perubahan atau pergantian dari satu merek ke merek yang lain (Peter \& Olson, 2010). Brand switching adalah saat dimana seorang pelanggan atau sekelompok pelanggan berpindah kesetiaan dari satu merek sebuah produk tertentu ke merek produk lainnya (Spacey, 2017).

Menurut Swastha (Swastha \& Irawan, 2005) ada dua kategori perpindahan merek. Kategori pertama, perpindahan konsumen didasarkan pada keputusan pribadi, yang kedua perilaku brand switching dilakukan secara tidak segaja tanpa dipengaruhi pertimbangan pribadi. Perpindahan merek merupakan gambaran dari beralihnya pengkonsumsian konsumen atas suatu produk ke produk lainnya. Hal ini dikarenakan seseorang selalu melakukan perbandingan antara merek satu dengan merek yang lain pada saat ia mengevaluasi merek tertentu atau pada saat ia membentuk sikapnya terhadap merek (Swastha, 2002).

Perpindahan merek dapat muncul karena adanya variety seeking. Menurut (Hoyer \& Ridgway, 1984) keputusan konsumen untuk berpindah merek tidak hanya dipengaruhi oleh variety seeking namun juga dipengaruhi oleh beberapa faktor seperti strategi keputusan (decision strategy), faktor situasional dan normatif, ketidakpuasan terhadap merek sebelumnya dan strategi pemecahan masalah (problem solving strategy). Penyebab lain perpindahan merek karena beragamnya produk lain dan adanya masalah dengan produk yang sudah dibeli.

\subsubsection{Faktor Penyebab Konsumen Beralih}

Ada beberapa faktor yang menyebabkan konsumen beralih dari satu merek ke merek lain (www.mars-e.com), yaitu kebutuhannya tidak terpenuhi dengan produk atau jasa yang sebelumnya digunakan (core product problem), tidak puas dengan layanan yang diberikan oleh pemilik merek (augmented product problem), ada merek lain yang memberikan benefit yang lebih baik (tidak berarti dissatisfied terhadap produk sebelumnya) dan ada keinginan untuk mencoba sesuatu yang lain (variety). Kendala yang dihadapi konsumen untuk pindah dari satu merek ke merek lain ternyata tidak sesederhana perasaan puas dan tidak puas saja. Hal ini juga berkaitan dengan adanya biaya (financial dan non financial) yang harus ditanggung oleh konsumen (Swastha, 2002).

Keaveney (1995) menemukan beberapa faktor penyebab perilaku perpindahan merek, antara lain harga, ketidaknyamanan, gagal memberi layanan yang baik, persaingan antar perusahaan dan masalah-masalah etika. Keputusan untuk berpindah dari merek satu ke merek lain merupakan fenomena kompleks yang dipengaruhi oleh faktor-faktor perilaku tertentu, skenario persaingan, dan waktu (Srinivasan, Biggers Jr, \& Latour Jr, 1996). Menurut Mazursky, Labarbera, \& Aiello (1987), perilaku perpindahan merek dapat disebabkan oleh faktor intrinsik dan ekstrinsik. Faktor instrinsik adalah faktor yang berasal dari dalam individu yang bersangkutan, misalnya adanya keinginan untuk mencoba merek baru. Sedangkan faktor ekstrinsik adalah faktor yang berasal dari luar, misalnya adanya diskon atau harga yang lebih murah.

\subsubsection{Indikator perpindahan merek}

Indikator perpindahan merek menurut Junaedi \& Swastha (2002) adalah kognitif, afektif, konatif, tindakan. 


\subsection{Ketidakpuasan Konsumen}

\subsubsection{Pengertian Ketidakpuasan Konsumen}

Ketidakpuasaan konsumen dapat membawa konsumen pada sikap kecewa bahkan lebih marah pada produk tersebut dan memiliki pertimbangan lebih lanjut untuk memutuskan atau meninggalkan produk tersebut (Stephens \& Gwinner, 1998). Ketidakpuasan yang dialami konsumen akan menimbulkan perilaku peralihan merek. Ketidakpuasan konsumen ini muncul karena pengharapan konsumen tidak sama atau lebih tinggi daripada kinerja yang diterimanya di pasar (Swastha, 2002).

Ketidakpuasan konsumen terjadi apabila kinerja suatu produk tidak sesuai dengan persepsi dan harapan konsumen (Kotler \& Keller, 2016). Ketidakpuasan terjadi ketika harapan konsumen tidak terpenuhi, sehingga konsumen akan bersikap negatif terhadap suatu merek dan kecil kemungkinannya konsumen akan membeli lagi merek yang sama. Junaedi \& Swastha (2002) membuat kesimpulan bahwa ketidakpuasan akan menyebabkan perpindahan merek pada konsumen. Jadi, terdapat pengaruh positif ketidakpuasan terhadap keputusan perpindahan merek.

\subsubsection{Indikator Ketidakpuasan Konsumen}

Junaedi \& Swastha (2002) menemukan tiga hal yang menjadi indikator ketidakpuasan bagi konsumen yaitu nilai, manfaat, keinginan.

\subsection{Kebutuhan Mencari Variasi \\ 2.3.1 Pengertian Kebutuhan Mencari Variasi}

Mowen \& Minor (2000) mengemukakan bahwa mencari keragaman (variety-seeking) mengacu pada kecenderungan konsumen untuk mencari secara spontan membeli merek produk baru meskipun mereka terus mengungkapkan kepuasan mereka dengan merek yang lama. Menurut Mayasari (2005) bahwa kebutuhan mencari variasi adalah perilaku konsumen untuk melepaskan suatu kejenuhan karena keterlibatan rendah pada merek atau produk. Konsumen akan berusaha mencari keberagaman (variasi) merek (brand) diluar kebiasannya atau konsumen hanya sekedar mencoba sesuatu yang baru dari suatu produk dengan selera konsumen tersebut.

Pencarian variasi akan terjadi apabila tingkat keterlibatan konsumen pada suatu merek rendah dan konsumen menyadari adanya perbedaan anatara merek. Kebutuhan mencari variasi adalah sebuah komitmen kognitif untuk membeli merek yang berbeda karena berbagai alasan yang berbeda, keinginan baru atau timbulnya rasa bosan pada sesuatu yang telah lama dikonsumsi (Peter et al., 1999). Pencarian variasi akan terjadi apabila tingkat keterlibatan konsumen pada suatu merek rendah dan konsumen menyadari adanya perbedaan antara merek (Assael, 2004). Kebutuhan mencari variasi pada suatu kategori produk oleh konsumen merupakan suatu sikap konsumen yang ingin mencoba merek lain dan memuaskan rasa penasarannya terhadap merek lain serta diasosiasikan sebagai keinginan untuk berganti kebiasaan (Trijp et al., 1996).

\subsubsection{Tipe Konsumen Yang Mencari Variasi}

Schiffman \& Kanuk, (1994) membagi konsumen ke dalam beberapa tipe bagi yang mencari variasi yaitu : 1). Exploratory purchase behavior, merupakan keputusan perpindahan merek untuk mendapatkan pengalaman baru dan kemungkinan alternatif yang lebih baik. 2) Vicarious exporation, konsumen mencari informasi tentang suatu produk yang baru atau alternatif yang berbeda, kemudian mencoba untuk menggunakannya. 3). Use innovativeness, konsumen telah menggunakan dan mengadopsi suatu produk dengan mencari produk yang lebih baru dengan teknologi yang lebih tinggi.

\subsubsection{Indikator Kebutuhan Mencari Variasi}

Terdapat empat indikator kebutuhan konsumen dalam mencari variasi yaitu pilihan merek dalam pembelian, pilihan produk inovatif, pilihan harga, pengalaman mengkonsumsi suatu produk (Junaedi \& Swastha, 2002). 


\section{$3 \quad$ Metodologi}

Penelitian ini dilakukan di Fakultas Ekonomi Universitas Negeri Medan. Sampel berjumlah 95 mahasiswa yang pernah melakukan pembelian di toko online dan dipilih berdasarkan teknik sampel bertujuan. Kuesioner digunakan sebagai alat pengumpulan data. Penelitian ini menggunakan analisis regresi linear berganda untuk menganalisis data.

\section{Hasil dan Pembahasan}

\subsection{Hasil}

- Persamaan regresi memperoleh nilai $\mathrm{Y}=$ $0,723+0,371 X_{1}+0,435 X_{2}+\varepsilon$.

- Nilai konstanta 0,723 menjelaskan bahwa jika ketidakpuasan konsumen dan kebutuhan mencari variasi bernilai 0 , maka perilaku perpindahan toko bernilai 0,723 dengan asumsi faktor lain adalah konstan.

- Nilai Koefisien $X_{1}$ adalah 0,371 menjelaskan bahwa setiap peningkatan satu satuan ketidakpuasan konsumen akan mempengaruhi perilaku perpindahan toko senilai 0,371 dengan asumsi faktor lain adalah konstan.

- Nilai Koefisien $X_{2}$ adalah 0,435 menjelaskan bahwa setiap peningkatan satu satuan kebutuhan mencari variasi akan mempengaruhi perilaku perpindahan toko senilai 0,435 dengan asumsi faktor lain adalah konstan.

- Hasil uji t untuk ketidakpuasan konsumen bernilai 3,368, artinya ketidakpuasan konsumen secara parsial mempengaruhi perilaku konsumen berpindah toko dari Tokopedia ke Lazada.

- Untuk kebutuhan mencari variasi, nilai uji t yang diperoleh adalah 4,638, artinya bahwa kebutuhan konsumen mencari variasi secara parsial berpengaruh terhadap perilaku berpindah toko oleh konsumen.

- Nilai F sebesar 43,413 menunjukkan bahwa secara simultan ketidakpuasan konsumen dan kebutuhan mencari variasi secara positif dan signifikan mempengaruhi perilaku konsumen untuk pindah dari Tokopedia ke Lazada.

- Koefisien determinasi $\left(\mathrm{R}^{2}\right)$ bernilai 0,486, artinya $48,6 \%$ perilaku perpindahan toko oleh konsumen dijelaskan oleh ketidakpuasan konsumen dan kebutuhan mencari variasi. Sisanya senilai $51,4 \%$ dijelaskan oleh variabel lain di luar penelitian ini.

\subsection{Pembahasan}

Hasil penelitian ini menunjukkan bahwa terdapat pengaruh ketidakpuasan konsumen dan kebutuhan mencari variasi secara parsial terhadap perilaku perpindahan toko oleh konsumen dari Tokopedia ke Lazada. Hasil ini mendukung penelitian Leszczyc \& Timmermans (1997) yang menyatakan bahwa perilaku peralihan toko oleh konsumen disebabkan oleh kebutuhan konsumen yang ingin mencari variasi dimana hal ini terkait didorong oleh variabel sosiodemografi. Konsumen akan mencari sesuatu yang baru di toko lain salah satunya adalah nilai yang diperoleh diharapkan lebih tinggi dari yang diberi oleh toko sebelumnya (Rajagopal, 2011). Pernyataan ini tidak sejalan dengan (Mazursky et al., 1987). Mereka berpendapat bahwa perilaku perpindahan konsumen ke merek lain dipengaruhi oleh dua faktor yaitu intrinsik dan ekstrinsik. Faktor intrinsik seperti keinginan mencoba merek baru tidak memotivasi konsumen untuk beralih ke merek lain karena konsumen sudah merasa puas dengan merek yang terakhir dibeli.

Penelitian mengenai ketidakpuasan konsumen dilakukan oleh (Kumar \& Studies, 2016). Terdapat pengaruh yang signifikan dari pengaduan konsumen yang tidak puas terhadap perilaku peralihan ke toko lain. Pengaduan yang banyak berdasarkan kualifikasi pendidikan dan tingkat pendapatan. Sedangkan pengaduan konsumen yang tidak puas berdasarkan gender, usia dan status perkawinan, tidak mempengaruhi konsumen beralih ke toko lain. Sama halnya dengan yang dikemukakan oleh Hino \& Levy (2016). Mereka berpendapat bahwa ketidakpuasan konsumen akan menyebabkan konsumen 
pindah ke toko lain. Ketidakpuasan disebabkan oleh banyak faktor seperti kebersihan dan sanitasi toko serta penetapan harga produk. Akwensivie (2014) juga menyatakan bahwa banyak faktor yang menyebabkan konsumen berpindah toko, diantaranya tidak puas dengan sikap kasir, pelayanan yang kurang baik, barang yang kurang lengkap, tidak berlaku tawar menawar barang.

\section{Kesimpulan}

\subsection{Manfaat Penelitian}

Hasil penelitian ini diharapkan menjadi masukan bagi pemasar online untuk memanfaatkannya sebagai dasar pengembangan strategi bisnis dan evaluasi untuk strategi saat ini dalam menentukan perilaku konsumen berbelanja secara online. Pemasar online perlu memperhatikan kedua variabel ini (ketidakpuasan dan kebutuhan mencari variasi) sebagai faktor yang berpengaruh terhadap perilaku konsumen untuk pindah dari satu toko online ke toko online yang lain.

\subsection{Batasan}

1. Penelitian ini hanya dibatasi pada variabel ketidakpuasan konsumen dan kebutuhan mencari variasi.

2. Lama penelitian dan jumlah responden yang dianggap kurang memadai..

\subsection{Rekomendasi}

Peneliti selanjutnya diharapkan dapat mengikutsertakan variabel lain yang dapat mempengaruhi perilaku perpindahan toko oleh konsumen seperti harga, pelayanan, kualitas produk dan sebagainya. Selain itu, diharapkan penelitian selanjutnya dapat menambah jumlah responden yang lebih banyak untuk mendapatkan hasil yang lebih akurat. Metode penelitian yang lebih tepat juga disarankan agar diperoleh hasil penelitian yang lebih maksimal.

\section{Referensi}

Admin. (2017a). kunci-sukses-mengatasipersaingan-bisnis-toko-online. Retrieved September 10, 2017, from https://infopeluangusaha.org/kuncisukses-mengatasi-persaingan-bisnistoko-online/

Admin. (2017b). Strategi Memenangkan Persaingan Toko Online Tanpa Turunkan Harga. Retrieved September 11, 2017, from https://www.maxmanroe.com/

Akwensivie, D. M. (2014). Switching Behaviour And Customer Relationship Management- The Iceland Experience.

British Journal of Marketing Studies, 2(1), 89100.

Arianto, A. B. (2013). Pengaruh Atribut Produk , Harga , Kebutuhan Mencari Variasi dan Ketidakpuasan Konsumen terhadap Keputusan Perpindahan Merek dari Samsung Galaxy Series di Kota Malang. Jurnal Aplikasi Manajemen, 11(2), 294-305.

Assael, H. (2004). Consumer Behavior and Marketing Action. New York: International Thomson Publishing Company.

Handayai, S. N. (2016, October). Jadi Merek Potensial, Ini Kuncinya. Majalah Swa. Retrieved from https://swa.co.id/swa/businessstrategy/jadi-merek-potensial-inikuncinya

Handayani, R., \& Maharani, E. (2017, September). Ini Tiga Toko Online Favorit Masyarakat Indonesia. Republika.co.id. Retrieved from http://gayahidup.republika.co.id/berita/g aya-hidup/trend/17/09/06/ovti91335- initiga-toko-online-favorit-masyarakatindonesia

Hino, H., \& Levy, S. (2016). Determinants for store-switching in shopping for fresh produce: investigating the mediating role of consumer way of life. The International Review of Retail, Distribution and Consumer Research, 26(5), 541-565. https://doi.org/10.1080/09593969.2016.1 206951

Hoyer, W. D., \& Ridgway, N. M. (1984). Variety Seeking As an Explanation For 
Exploratory Purchase Behavior: a Theoretical Model. Advances in Consumer Research, 11, 114-119. Retrieved from http://www.acrwebsite.org/search/viewconference-proceedings.aspx $? \mathrm{Id}=6226$

Ishadi, I. D. (2012). Analisis Pengaruh Ketidakpuasan Konsumen, Iklan Pesaing Dan Perilaku Mencari Variasi Terhadap Perilaku Perpindahan Merek Pada Konsumen Shampo Sunsilk. Diponegoro Journal of Management, 1(2), 343-351.

Junaedi, S., \& Swastha, B. (2002). Pengaruh Ketidakpuasan Konsumen, Karakteristik Kategori Produk, dan Kebutuhan Mencari Variasi terhadap Keputusan Perpindahan Merek. Jurnal Ekonomi Dan Bisnis Indonesia, 17(1), 91-104.

Keaveney, S. M. (1995). Customer Switching Behavior in Service Industries: An Expioratory Study. Journal of Marketing, 59(2), 71-82. https://doi.org/10.2307/1252074

Kotler, P., \& Keller, K. L. (2012). Marketing Management. Dictionary of Marketing Communications.

https://doi.org/10.4135/9781452229669. n2040

Kotler, P., \& Keller, K. L. (2016). Marketing Management (15 Global). England: Pearson.

Kumar, P., \& Studies, M. (2016). Impact Of Customer Complaining Behaviour On Defection Behaviour: An Investigation On Retail, 4, 214-225.

Leszczyc, P. T. L. P., \& Timmermans, H. J. P. (1997). Store-Switching Behavior, 2, 193-204.

Mayasari, I. (2005). Pengaruh Aspek Internal Individu Pada Perilaku Pencarian Variasi serta Dampaknya Pada Loyalitas Kesikapan.

Universitas Gajah Mada. Retrieved from https://scholar.google.co.id/citations?view_ $\mathrm{op}=$ view_citation $\& \mathrm{hl}=\mathrm{en} \& \mathrm{user}=5 \mathrm{jKf} 5 \mathrm{AQ}$ AAAAJ\&citation_for_vi ew=5jKf5AQAAAAJ:aqlVkmm33-oC
Mazursky, D., Labarbera, P., \& Aiello, A. (1987). When consumers switch brands. Psychology \& Marketing, 4(1), 17-30. https://doi.org/10.1002/mar.4220040104

Mowen, J. c, \& Minor, M. (2000). Consumer Behavior: A framework. New Jersey: Prentice Hall.

Peter, J. P., \& Olson, J. C. (2010). Consumer Behavior \& Marketing Strategy. New York: Mc Graw Hill Companies Inc.

Peter, J. P., Olson, J. C., \& Grunert, K. G. (1999). Consumer Behavior and Marketing Strategy. New York: Mac Graw Hill Companies Inc.

Prihadi, S. D. (2017, March 15). petapersaingan-situs-e-commerce-di-

indonesia. CNN Indonesia. Jakarta.

Retrieved from

https://www.cnnindonesia.com /teknologi/20170315104148-185-

200219/peta-persaingan-situs-ecommerce-di-indonesia/

Rahman, A. F. (2017, September 5). masyarakat-indonesia-makin-doyanbelanja-online-tapi. Detik.com. Jakarta. Retrieved from https://inet.detik.com/cyberlife/d3630020/masyarakat-indonesia-makindoyan-belanja-online- tapi....

Rajagopal. (2011). Influence of store brands on variety-seeking behaviour of consumers in Mexico Rajagopal.

International Journal Built Environment and Asset Management, 1(1), 56-73.

Schiffman, L. G., \& Kanuk, L. L. (1994). Consumer Behavior. New Jersey: Prentice Hall.

Spacey, J. (2017). 9 Types of Brand Switching. Retrieved September 10, 2017, from https://simplicable.com/new/brandswitching

Srinivasan, S., Biggers Jr, S. B., \& Latour Jr, R. A. (1996). Identifying Global / Local Interface Boundaries Using An Objective Search Method. International Journal For Numerical Methods In Engineering, 39(July 1994), 805-828.

Stephens, N., \& Gwinner, K. P. (1998). Why 
Don't Some People Complain? A Cognitive-Emotive Process Model of Consumer Complaint Behavior. Journal of the Academy of Marketing Science, 26(3), 172-189. https://doi.org/10.1177/00920703982630 01

Swastha, B. (2002). Manajemen Pemasaran (Kedua). Jakarta: Liberty.

Swastha, B., \& Irawan. (2005). Manajemen Pemasaran Modern. Yogyakarta: Liberty.

Trijp, H. C. M. Van, Hoyer, W. D., \& Inman, J. J. (1996). Why Switch? Product Category: Level Explanations for True Variety-Seeking Behavior. Journal of Marketing Research, 33(3), 281-292. https://doi.org/10.2307/3152125 